\title{
PENGEMBANGAN E-LEARNING BERBASIS MOODLE UNTUK MENINGKATKAN PEMAHAMAN ISI TEKS ANEKDOT PADA SISWA SMA KELAS X
}

\author{
Abdul Haris Munandar \\ Program Studi Teknologi Pembelajaran \\ Pascasarjana Universitas Negeri Yogyakarta \\ abdulharismunandar95@yahoo.co.id \\ Herman Dwi Surjono \\ Program Studi Teknologi Pembelajaran \\ Pascasarjana Universitas Negeri Yogyakarta \\ hermansurjono@uny.ac.id
}

\begin{abstract}
Abstrak: Penelitian ini bertujuan untuk: (1) menghasilkan e-learning berbasis Moodle untuk meningkatkan pemahaman isi teks anekdot pada siswa SMA Kelas X; (2) mengetahui kelayakan elearning; (3) mengetahui efektivitas pembelajaran Bahasa Indonesia setelah menggunakan elearning. Model pengembangan yang digunakan adalah model pengembangan yang diadaptasikan dari model Alessi dan Trollip. Prosedur pengembangan meliputi tahap perencanaan, desain dan pengembangan. Hasil penelitian menunjukkan bahwa: (1) produk e-learning berbasis Moodle untuk meningkatkan pemahaman isi teks anekdot anekdot pada siswa SMA Kelas X dihasilkan sesuai dengan model pengembangan Alessi dan Trollip (2001) melalui tiga tahap, yakni perencanaan, perancangan, dan pengembangan; (2) produk e-learning berbasis Moodle untuk meningkatkan pemahaman isi teks anekdot pada siswa SMA kelas X dinyatakan layak digunakan dalan proses pembelajaran ditinjau dari media, materi, dan penilaian siswa; (3) Produk e-learning yang dikembangkan menggunakan aplikasi Moodle dinilai efektif karena dapat meningkatkan pemahaman isi teks anekdot. Hal ini dibuktikan dengan hasil nilai pretest dengan rata-rata 66,88, dan nilai posttest dengan rata-rata nilai 93,63. Porsentase ketuntasan belajar siswa 100\% (32 siswa). Dari hasil penelitian tersebut, dapat disimpulkan bahwa e-learning yang dikembangkan layak, dan efektif digunakan dalam pembelajaran khususnya pada materi teks anekdot.
\end{abstract}

Kata Kunci: e-learning, moodle, efektivitas, teks anekdot

Abstract: This study aims to: (1) produce e-learning based on Moodle to increase the understanding of the anecdotes text content of senior high school students class X; (2) determine the feasibility of e-learning; (3) determine the effectiveness of learning Indonesian after using $e$ learning. The development model used a model adapted from the Alessi \& Trollip. The procedure included the development of planning, design, and development. The result shows that: (1) the product Moodle-based e-learning inproved the understanding of the text content of anecdotes in SMA students class $X$ is produced in accordance with the development model Alessi and Trollip (2001) through three stages: planning, design, and development; (2) the product Moodle-based elearning improved the understanding of the anecdotes text content in SMA students class $X$ and is declared eligible for use in the leaning process in terms of media, materials, and student's assessment; (3) e-learning products development using Moodle application is considered effective because it could improve the understanding of the text content of anecdotes. This is evidenced by the result of the pretest with an average of 66.88, and posttest volue with an average of 93.63. The precentage of complete mastery of the student learning is 100\% (32 students). From these results, it could be concluded that the e-learning developed is feasible, and effective to be used in learning, especially on anecdotes text material.

Keywords: e-learning, moodle, effectiveness, anecdotes text

\section{PENDAHULUAN}

Bahasa adalah alat komunikasi antar anggota masyarakat berupa simbol bunyi yang dihasilkan oleh alat ucap manusia (Keraf, 2004, p.1). Kemudian menurut Kridalaksana (1983), dan Kentjono (1982) dalam Chaer (2007, p.32) 
bahwa bahasa adalah sistem lambang bunyi yang arbitrer yang digunakan oleh para anggota kelompok sosial untuk bekerja sama, berkomunikasi, dan mengidentifikasi diri. Dari dua definisi tersebut dapat disimpulkan bahwa bahasa merupakan sistem lambang bunyi yang digunakan sebagai alat komunikasi antar kelompok sosial untuk bekerja sama, berkomunikasi, dan mengidentifikasi diri. Jadi bahasa Indonesia digunakan sebagai alat komunikasi antar masyarakat yang ada dalam kawasan Indonesia.

Bahasa Indonesia berasal dari bahasa Melayu Riau, dan kemudian digunakan sebagai bahasa Indonesia. Pemilihan bahasa Melayu Riau sebagai bahasa nasional, karena, (1) bahasa Melayu berfungsi sebagai lingua franca, (2) bahasa Melayu sederhana karena tidak mengenal tingkatan bahasa, (3) bahasa melayu dijadikan bahasa kebudayaan. Bahasa Melayu sudah dipakai sejak zaman kerajaan Sriwijaya, dan kemudian dikukuhkan sebagai bahasa persatuan bangsa Indonesia yang tertera pada isi sumpah pemuda pada tanggal 28 Oktober 1928 yang menyatakan bahwa kami putera, dan puteri Indonesia menjunjung bahasa persatuan, bahasa Indonesia. Kemudian pengokohan bahasa Indonesia sebagai bahasa nasional di dalam UUD 1945 di sebutkan bahwa "bahasa negara adalah bahasa Indonesia, (pasal 36). Proklamasi Kemerdekaan Republik Indonesia pada tanggal 17 Agustus 1945, telah mengukuhkan kedudukan, dan fungsi bahasa Indonesia secara konstitusional sebagai bahasa Negara.

Bahasa Indonesia juga salah satu mata pelajaran wajib A dalam kurikulum 2013 mulai dari sekolah dasar sampai sekolah menengah atas dan mata kuliah umum pada jenjang perguruan tinggi. Kemudian kedudukan materi pelajaran bahasa di kurikulum 2013 adalah sebagai (1) penghela mata pelajaran lain (sikap dan keterampilan berbahasa), (2) alat komunikasi dan carrier of knowledge, (3) alat komunikasi untuk menyampaikan gagasan dan pengetahuan, (4) membaca dan memahami makna teks, (5) menyusun teks yang sistematis, logis dan sistematis dan efektif, (6) dikenalkan dengan aturan-aturan teks yang sesuai, dan (7) mengekspresikan diri dan pengetahuan (Amiruddin, 2013, p.1). Dari beberapa kedudukan mata pelajaran bahasa Indonesia tersebut dapat disimpulkan bahwa mata pelajaran bahasa Indonesia sangat penting untuk dipelajari karena dapat membantu mempelajari mata pelajaran lainnya.

Pembelajaran bahasa Indonesia tingkat SMA pada kurikulum 2013 menerapkan pendekatan berbasis teks, baik lisan maupun tulis, dengan menempatkan bahasa Indonesia sebagai wahana untuk mengekspresikan perasaan dan pikiran. Kemudian pembelajaran bahasa Indonesia bukan sekadar sebagai pengetahuan bahasa, melainkan sebagai teks yang mengemban fungsi untuk menjadi sumber aktualisasi diri penggunanya pada konteks sosial budaya akademik. Teks dimaknai sebagai satuan bahasa yang mengungkapkan makna secara kontekstual.

Mata pelajaran bahasa Indonesia dianggap penting untuk diajarkan di sekolah karena memiliki peran dalam perkembangan intelektual, sosial dan emosional dan merupakan penunjang dalam mempelajari semua bidang studi (BSNP 2006a) serta untuk meningkatkan kemampuan siswa dalam bersosialisasi dengan sesama dalam berbagai kesempatan baik resmi maupun tidak resmi, tulis maupun lisan (BSNP 2006a: 1) dalam Sufanti (2010, p.12).

Dalam meningkatkan kemampuan tersebut dibutuhkan suatu proses pembelajaran yang ideal. Pembelajaran ideal menurut Peraturan Menteri Nasional Nomor 41 Tahun 2007, tentang standar proses untuk Satuan Pendidikan Dasar dan Menengah adalah proses pembelajaran pada setiap satuan pendidikan dasar dan menengah harus interaktif, inspiratif, menyenangkan, menantang, dan memotivasi peserta didik untuk berpartisipasi aktif, serta memberikan ruang yang cukup bagi prakarsa, kreativitas, dan kemandirian sesuai dengan bakat, minat, dan perkembangan fisik serta psikologis peserta didik (Depdiknas, 2007, p.424).

Pembelajaran ideal akan terlaksana dengan baik apabila komponen-komponen dalam sistem pembelajaran berperan secara optimal. komponen-komponen sistem pembelajaran yang dimaksud adalah manusia (man), teknologi media (devise), strategi pembelajaran (technique), lingkungan belajar (setting), sumber belajar (material) dan pesan pembelajaran (message).

Salah satu komponen sistem pembelajaran tersebut di era perkembangan teknologi informasi dan komunikasi sekarang ini yang ikut meq mbantu dalam mempermudah proses pembelajaran, yakni 
teknologi media (devise). Media pembelajaran bukan hanya sekedar alat bantu saja, namun juga dapat membantu dalam menyajikan dan menyalurkan pesan (Sadiman, Rahardjo, Haryono, \& Rahardjito, 2012, p.10). Dengan adanya media, keberadaan guru di kelas bukan sebagai sumber belajar yang utama, melainkan memberikan bimbingan secara individual kepada siswa-siswanya.

Kegiatan belajar mengajar yang tidak didukung dengan media yang tepat, dapat membuat materi pelajaran tidak disampaikan dengan maksimal, sehingga peserta didik tidak dengan maksimal menangkap materi yang disampaikan. Salah satu dampak positif dari penggunaan media pembelajaran adalah dapat meningkatkan kualitas hasil belajar serta dapat mempersingkat waktu pembelajaran karena dapat menyajikan materi pelajaran dalam jumlah yang banyak dan peserta didik dapat menyerapnya (Arsyad, 2014, p.26).

Berbagai media pembelajaran telah banyak dikembangkan untuk menunjang proses pembelajaran sekarang ini. Salah satu media pembelajaran yang memungkinkan peserta didik untuk belajar dimana dan kapanpun (Fleksibilitas) dan dapat menyampaikan materi dengan baik dan siswa dapat mengakses materi tersebut dengan baik (distribusi) adalah $e$ learning. Definisi e-learning yang dimaksud seperti yang diungkapkan oleh Horton (2006, p.1) dengan menyebutkan bahwa "e-learning is the use of information and computer technologies to create learning experiences". E-learning adalah penggunaan informasi dan komputer untuk menciptakan pengalaman belajar. Sejalan dengan pendapat tersebut, bahwa e-learning adalah istilah generik dari pendayagunaan teknologi elektronik untuk pembelajaraan (Prawiradilaga, Ariani, \& Handoko, 2013, p.33). Istilah-istilah tersebut lebih mengacu kepada e-learning yang bersifat online learning.

Berdasarkan hasil penelitian yang dilakukan oleh Hartawan, Tastra, \& Pudjawan, K. (2014, p.11), Nurhadi (2010, p.207), dan Helianak, \& Surjono (2014, p.14) yang menunjukkan bahwa dengan menggunaan $e$ learning dapat meningkatkan hasil belajar dan motivasi belajar siswa. Bukan hanya itu, media pembelajaran dapat memfasilitasi adanya keterbatasan ruang dan waktu antara siswa dengan guru, siswa dengan siswa serta siswa dengan materi. Dengan perannya media seperti ini dapat membantu guru yang berhalangan hadir dalam proses pembelajaran di kelas.

Kemudian berbagai lembaga pendidikan sekarang ini, telah banyak memanfaatkan $e$ learning dalam memfasilitasi proses belajar mengajar khususnya Moodle (Modular ObjectOriented Dynamic Learning Environmnet). Menurut Baskoro (2014, p.2) mengatakan bahwa lebih dari 235 Negara telah menggunakan aplikasi Moodle, jumlah pengguna yang telah melakukan registrasi sejumlah 71.604.026, jumlah pengajar 1.157.296 dan sebagai peserta pembelajaran 103.838.988 orang. Salah satu penyebab banyaknya penggunaan Moodle adalah sebuah perangkat lunak LMS (Learning Management System) yang Open Source dan mempunyai banyak fitur di dalamnya, sehingga mempermudah dalam pengembangannya.

Di Indonesia sendiri sudah banyak sekolah menengah atas yang sudah menggunakan e-learning berbasis Moodle untuk digunakan sebagai media pembelajaran online seperti di (1) SMA 8 Yogyakarta dengan url: http://elearning.sman8yogya.sch.id/.

SMA Negeri 9 Kota Jambi dengan url: http://elearning.sma9jambi.sch.id/. (3) SMA Negeri 1 Banda dengan url: http://elearning.sma1banda.sch.id/. (4) SMA Negeri 103 Jakarta dengan url: http://elearning.sma103jakarta.sch.id/. (5) SMA Negeri 2 Jayapura dengan url: http://sman2jayapura.sch.id/. (6) SMA Negeri 9 Bandar lampung dengan url: http://smalan.sch.id/e-learning/. (7) SMA Negeri 1 Kota Gajah dengan url: http://1ms.sma1kotagajah.sch.id/. Dari beberapa sekolah tersebut telah memuat semua mata pelajaran mulai dari kelas X sampai kelas XII termasuk mata pelajaran Bahasa Indonesia.

Kemudian ada juga sekolah-sekolah yang sudah mempunyai web yang hanya sebatas memuat profil sekolah, pengumuman, kegiatan sekolah, galeri dll. Sekolah-sekolah tersebut seperti (1) SMA Negeri 1 Godean dengan url: http://sman1godean.sch.id/. (2) SMA Negeri 1 Mataram dengan url: http://www.sman-1-mtr.sch.id/. (3) SMA Negeri 3 Kota Metro dengan url: http://www.sman3metro.sch.id/. (4) SMA Negeri 1 Praya dengan url: http://www.sman1praya.sch.id/. (5) SMA Negeri 110 Jakarta dengan url: http://sman110.sch.id/. Sekolah-sekolah tersebut sudah mempunyai daya dukung untuk 
dikembangkan sebuah media pembelajaran online yang digunakan untuk proses pembelajaran. Apabila tidak dimanfaatkan untuk dikembangkan sebuah media pembelajaran online, maka daya dukung tersebut tidak bisa meningkatkan pelayanan dan kualitas pembelajaran apalagi hosting dan domain prabayar setiap tahunnya.

Kemudian peneliti mengambil salah satu dari sekolah tersebut untuk dijadikan sebagai tempat penelitian dan kemudian akan dikembangkan sebuah e-learning untuk digunakan sebagai media pembelajaran online. Sekolah yang diambil adalah SMA Negeri 1 Godean. Berdasarkan hasil survei pada tanggal 16 November 2015 di SMA Negeri 1 Godean bahwa sekolah tersebut belum menggunakan media pembelajaran online (e-learning) yang dirancang khusus untuk proses pembelajaran. Padahal telah mempunyai fasilitas penunjang dalam menggunakan e-learning, antara lain sebuah lab komputer yang berisi 65 unit komputer beserta perangkat lainnya, wi-fi (Munandar, 2015, p1). Kemudian dari siswa dan guru sudah terbiasa menggunakan internet dalam menunjang proses pembelajaran. Bahkan rata-rata siswa kelas $X$ MIPA yang akan dijadikan subjek penelitian telah mempunyai $e$ mail untuk digunakan dalam mengumpulkan tugas sekolah.

Berdasarkan hasil analisis kebutuhan bahwa guru mata pelajaran bahasa Indonesia kelas X MIPA telah memanfaatkan internet, namun hanya sebatas mencari materi pembanding dan men-download buku paket. Materi dan buku teks tersebut hanya bersifat verbal, artinya bahwa guru hanya menyajikan materi yang berbentuk teks. Kemudian siswa juga sudah biasa memanfaatkan internet untuk mencari materi tambahan dan mengerjakan tugas. Namun hal tersebut juga menimbulkan sebuah masalah, karena kadang peserta didik mendapatkan materi yang tidak sesuai dengan kompetensi yang dipelajari. Salah satu contohnya adalah ketika siswa disuruh mencari jenis-jenis kata dalam kosa kata bahasa Indonesia, siswa menemukan jenis kata lampau dalam istilah kosa kata bahasa Inggris yang terjemahan bahasa Indonesia. Namun dalam kosa kata bahasa Indonesia tidak ada istilah kosa kata lampau. Dengan adanya kejadian tersebut dibutuhkan sebuah media pembelajaran online yang memang dengan sengaja untuk dikembangkan dan kemudian peserta didik dapat mengakses materi di media online tersebut.

Menurut guru bahasa Indonesia kelas $\mathrm{X}$ di SMA Negeri 1 Godean, bahwa ada salah satu materi yang masih banyak peserta didik belum mencapai KKM, yakni teks anekdot. Materi tentang teks anekdot ini baru diperkenalkan pada jenjang SMA pada kelas 10 semester 2 pada kurikulum 2013, sehingga materi ini masih terasa asing dipelajari oleh peserta didik. Hal tersebut didukung oleh hasil wawancara dengan peserta didik bahwa mereka belum pernah mempelajari atau bahkan belum pernah mendengar istilah teks anekdot. Kemudian siswa juga masih kesulitan mengaitkan struktur teks anekdot dengan teks anekdot. Struktur teks anekdot meliputi: abstraksi, orientasi, krisis, reaksi dan koda. Pendapat tersebut diperkuat oleh hasil penelitian yang dilakukan oleh Rahmayanti, Martha, \& Wisudariani (2015, p.10) bahwa siswa masih kesulitan dalam menyusun teks anekdot berdasarkan strukturnya serta siswa masih kesulitan dalam menyatukan padukan unsur lucu bernuansa sindiran.

Masalah lain yang ditemukan adalah kurangnya bahan yang praktis dan komprehensif. Kebanyakan bahan ajar yang digunakan masih mengandalkan buku paket dan lembar kerja kerja siswa (LKS). Hal tersebut membuat peserta didik merasa materi kurang lengkap dan praktis untuk dipelajari serta untuk mengeksplornya. Selain dari pada itu, materi pelajaran yang tidak didukung dengan ilustrasi atau video membuat siswa sedikit kesulitan menangkap materi yang disampaikan. Bahan ajar yang didukung oleh berbagai bahan ajar misalnya: teks, audio, audio visual serta video dapat membantu peserta didik dalam menangkap materi yang sampaikan.

Selain dari pada itu, alokasi waktu yang dirasa kurang untuk menyampaikan materi, sehingga guru hanya fokus pada bagaimana semua materi pelajaran yang ada pada kurikulum bisa disampaikan semuanya. Hal tersebut membuat tujuan utama pembelajaran adalah tercapainya tujuan pembelajaran tidak terlalu diperhatikan. Masalah ini sudah menjadi rahasia umum bagi dunia pendidikan di Indonesia. Apalagi seandainya guru berhalangan hadir, maka proses pembelajaran tidak akan berjalan dengan baik. Hal ini juga membuat materi pelajaran tertinggal.

Berdasarkan analisis kebutuhan di lapangan, untuk dapat membantu pendidik dan peserta didik memecahkan masalah yang 
sedang dialami tersebut dibutuhkan inovasi dalam pembelajaran. Inovasi tersebut berupa pemanfaatan perkembangan teknologi informasi dan komunikasi, yakni penggunaan media pembelajaran berbasis online (elearning).

E-learning telah lama dianggap sebagai terobosan baru yang dahsyat dalam dunia pendidikan serta merupakan bagian terpenting dalam upaya meningkatkan kualitas proses belajar mengajar. E-learning adalah salah satu media pembelajaran berbasis Learning Management System (LMS). Yang artinya, bahwa sistem perangkat lunak yang memvirtualisasikan proses belajar mengajar konvensional. Karakter utama LSM adalah pengguna yang merupakan guru dan siswa dan keduanya harus terkoneksi internet untuk menggunakan aplikasi ini. Dengan adanya LSM ini, proses pembelajaran tidak lagi terpaku pada pembelajaran konvensional yang hanya bisa diselenggarakan di ruang dan waktu yang sama. Namun, bisa dilaksanakan pada ruang dan waktu yang berbeda (anywhere and anytime learning and teaching).

Dari uraian tersebut, maka perlu untuk dilakukan pengembangan terhadap media belajar dalam hal pengembangan e-learning berbasis Moodle yang memanfaatkan teknologi internet dalam proses pembelajaran yang dapat digunakan sebagai media pembelajaran pembelajaran bahasa Indonesia khusus berkaitan dengan teks anekdot.

Berdasarkan latar belakang masalah tersebut, maka rumusan masalah pada penelitian dan pengembangan ini adalah: (1) Bagaimana menghasilkan e-learning berbasis Moodle untuk meningkatkan pemahaman isi teks anekdot anekdot pada siswa SMA Kelas X yang layak dari aspek media dan materi? ; (2) Bagaimana efektivitas pembelajaran Bahasa Indonesia khususnya untuk meningkatkan pemahaman isi teks anekdot pada siswa SMA kelas $\mathrm{X}$ dengan menggunakan e-learning berbasis Moodle?

Berdasarkan rumusan masalah tersebut, maka tujuan penelitian dan pengembangan ini adalah: (1) Untuk menghasilkan e-learning berbasis Moodle untuk meningkatkan pemahaman isi teks anekdot anekdot pada siswa SMA Kelas X yang layak dari aspek media dan materi; (2) Untuk mengetahui efektivitas pembelajaran Bahasa Indonesia khususnya untuk meningkatkan pemahaman isi teks anekdot pada siswa SMA kelas $\mathrm{X}$ dengan menggunakan e-learning berbasis Moodle.

Clark \& Mayer (2008, p.10) menyebutkan e-learning as instruction delivered on a computer by way of CD-ROM, internet, or intranet. E-learning dapat diartikan sebagai pelajaran disampaikan menggunakan komputer melalui CD-ROM, internet atau intranet. Jadi bisa disimpulkan bahwa $e$ learning ada yang bersifat online (internet atau intranet) dan offline (CD-ROOM). Kemudian menurut Horton \& Horton (2003, p.13) yang mengartikan e-learning sebagai any use of web and internet technologies to create learning experiences. E-learning dapat diartikan sebagai penggunaan teknologi web atau internet untuk membuat pengalaman belajar. Dari dua pendapat tersebut mempunyai kesamaan yakni sama-sama menggunakan teknologi komputer, dan memanfaatkan jaringan internet dalam proses pembelajaran

Isaías, Ifenthaler, Spector, \& Sampson. (2015, p.2) menjelaskan bahwa e-learning mempunyai sifat fleksibilitas, dan pilihan serta dinamis. Artinya bahwa proses belajar mengajar dapat dilakukan dimana, dan kapan saja tanpa dibatasi ruang, dan waktu. Sejalan dengan itu, Surjono (2013, p.4) menjelaskan bahwa implementasi e-learning adalah sebagai upaya dalam pendistribusian materi pelajaran melalui media elektronik atau internet sehingga peserta didik dapat mengaksesnya kapan saja dari seluruh penjuru dunia. Dari penjelasan tersebut terdapat dua kata kunci dalam penggunaan $e$ learning adalah fleksibilitas, dan distribusi. Fleksibilitas artinya peserta didik dapat memilih waktu, dan tempat belajar karena mereka tidak harus datang di suatu tempat pada waktu yang sama. Distrubusi artinya pendidik dapat menyampaikan materi pelajaran menggunakan $\mathrm{CD}$ atau internet, sehingga peserta didik dapat mengakses dimana, dan kapanpun. Konsep $e$ learning dalam penelitian dan pengembangan ini adalah yang bersifat online.

Menurut Arkorful, \& Abaidoo (2014, p.401) mengatakan bahwa dengan adanya $e$ learning bisa memfokuskan pada kebutuhan peserta didik dalam hal belajar. Beberapa manfaat dengan adanya e-learning, yakni (1) dengan adanya e-learning peserta didik bisa menentukan waktu dan tempat dalam belajar; (2) dengan adanya e-learning dapat meningkatkan pengetahuan peserta didik melalui kemudahan akses informasi yang banyak; (3) dengan adanya e-learning 
memberikan kesempatan pada peserta didik berinteraksi dengan guru, peserta didik dengan peserta didik dan peserta didik serta peserta didik dengan materi; (4) dengan adanya $e$ learning dapat mengurangi biaya yang akan dikeluarkan oleh peserta didik serta dapat menampung peserta didik yang jumlahnya banyak walaupun gedung sekolah tidak banyak; (5) dengan adanya e-learning dapat mempertimbangkan perbedaan individu; (6) dengan adanya e-learning dapat mengatasi kelangkaan guru; (7) dengan adanya e-learning memberikan kesempatan kepada peserta didik untuk belajar sesuai dengan kecepatan belajar masing-masing peserta didik.

Menurut Haughey dalam Rusman, Kurniawan, \& Riyana (2012, p.292) ada tiga model e-learning, yakni seperti Gambar 1.

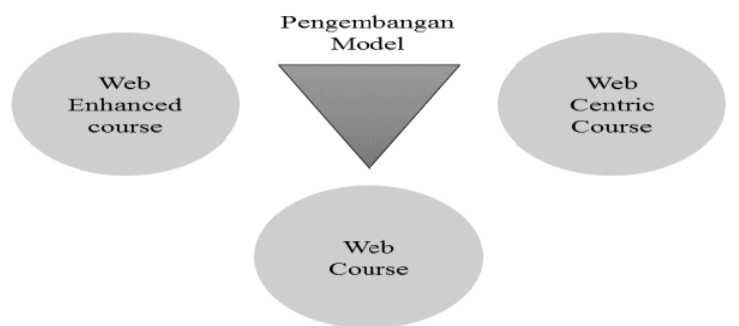

Gambar 1. Pengembangan model e-learning

Web course adalah suatu proses pembelajaran yang dimana pendidik dan peserta didik sepenuhnya terpisah baik itu tempat maupun waktu. Web centric course adalah suatu proses pembelajaran yang dimana memadukan antara pembelajaran jarak jauh dan tatap muka (konvensional). Web enhanced adalah suatu proses pembelajaran tatap muka (konvensional) memanfaatkan internet atau online learning untuk meningkatkan kualitas pembelajaran. Model e-learning yang digunakan dalam penelitian dan pengembangan adalah web centric course.

Conrad \& Training Links (2000, p.11) menggambarkan pembagian model penyajian $e$ learning berdasarkan bentuk interaksi penggunanya, yaitu: (1) Synchronous learning, yaitu sekelompok siswa dan guru bertemu melalui internet. (2) Self-directed learning, yaitu siswa bertindak sendiri untuk mengerjakan materi yang dikirimkan melalui internet. (3) Asynchronous (collaborative) learning, yakni gabungan dua metode sebelumnya, pendidik dan peserta didik dalam kelas yang sama (kelas virtual), tapi dalam waktu dan tempat yang berbeda.

\section{METODE}

Penelitian ini lakukan di SMA Negeri 1 Godean selama 6 bulan dari bulan November 2015-Mei 2016. Subjek penelitian dan pengembangan ini adalah dua orang ahli media dan dua orang ahli materi untuk uji Alfa, tiga orang siswa yang mewakili kemampuan tinggi, sedang dan rendah untuk uji coba beta, dan satu kelas X SMA Negeri 1 Godean yang berjumlah 32 orang untuk uji efektivitas.

Penelitian ini menggunakan pendekatan kuantitatif dengan jenis penelitian pengembangan (R\&D) yang mengacu pada model pengembangan dari Alessi \& Trollip (2001) yang terdiri atas tiga tahap, yakni planning, design dan development. Serta tiga atribut, yakni standards, project management dan ongoing evaluation.

Prosedur penelitian dan pengembangan ini adalah sebagai berikut: (1) perencanaan meliputi: menetapkan bidang atau ruang lingkup kajian, mengidentifikasi karakteristik peserta didik, menentukan dan mengumpulkan sumber-sumber, dan melakukan brainstorming; (2) Perancangan meliputi: melakukan analisis konsep, membuat flowchart, dan mengembangkan layout; (3) pengembangan meliputi: membangun e-learning dengan domain dan hosting, mengembangkan konten, menggabungkan bagian-bagian, menyiapkan materi tambahan, tes alfa, tes beta, dan uji efektivitas.

Tes alfa merupakan tes internal yang formal, melibatkan pengembang bersama tim, yakni ahli media, ahli materi. Pada tes alfa, ahli media akan memberikan penilaian dari segi tampilan media dengan tujuan mengantisipasi kesalahan tampilan yang dapat mengakibatkan kurang baiknya media yang dikembangkan. Masukan dari ahli sangat diperlukan sebagai bahan dalam melaksanakan revisi sehingga produk yang dikembangkan benar-benar teruji dari segi media. Sedangkan ahli materi akan memberikan masukan dari segi pembelajaran, dan isi materi pembelajaran. Masukan dari ahli materi sangat diperlukan sebagai bahan dalam melakukan revisi sehingga produk yang dikembangkan benar-benar teruji dari segi materi. selain dari pada itu, data yang diperoleh dari tes alfa ini adalah data kuantitatif berupa skor dengan menggunakan skala penilaian, yakni skala lima untuk mengetahui kelayakan dari kedua ahli. Aspek media dan materi dinyatakan layak apabila telah memenuhi standar minimal kelayakan yang telah 
ditentukan, yakni apabila mencapai kategori cukup dengan rentang skor skor $2,6<\mathrm{X} \leq 3,4$.

Tes beta merupakan tes formal yang sepenuhnya dilakukan oleh siswa setelah menggunakan e-learning yang sudah direvisi pada tahap pertama setelah tes alfa. Siswa yang mengikuti seleksi tes beta adalah siswa yang belum pernah menggunakan produk. Setelah tes beta dilakukan, produk direvisi (revisi akhir) sehingg produk siap digunakan di kelas nyata pada saat uji validasi produk atau sumatif.

Uji efektifivitas atau tes sumatif dilakukan secara formal untuk mengetahui ada tidaknya pengaruh penggunaan e-learning terhadap efektivitas pembelajaran yang ditinjau dari peningkatan hasil belajar. E-learning dinyatakan efektif apabila adanya peningkatan yang signifikan antara hasil pretest, dan posttest serta ditinjau dari pencapaian hasil posttest dengan KKM 75 yang telah ditetapkan oleh SMA Negeri 1 Godean untuk kelas X.

Jenis data yang digunakan dalam penelitian dan pengembangan ini adalah data kualitatif dan kuantitatif. Data kualitatif diperoleh dari masukan dari ahli media dan materi pada saat uji coba alfa. Data kualitatif ini digunakan untuk memperbaiki produk yang dikembangkan sesuai dengan masukan dari para ahli. Sedangkan data kuantitatif diperoleh dari hasil validasi dari ahli media dan materi pada saat uji coba alfa serta hasil penilaian siswa pada saat uji coba beta. Data kuantitatif ini digunakan untuk menilai kelayakan produk yang dikembangkan dari aspek media dan materi.

Teknik pengumpulan data yang digunakan dalam penelitian dan pengembangan ini adalah angket dan tes. Angket ditujukan pada dua ahli media, dua ahli materi dan tiga orang peserta yang mewakili kemampuan tinggi, sedang, dan rendah untuk menilai kelayakan produk dari aspek media dan materi. Sedangkan tes ditujukan pada satu kelas di SMA Negeri 1 Godean, yakni kelas x MIPA 3 yang berjumlah 32 orang siswa digunakan untuk menilai keefektivitas produk.

Instrumen pengumpulan data yang digunakan dalam penelitian dan pengembangan ini adalah lembar validasi (angket) dengan menggunakan skala lima dan soal pre-test dan post-test.

Angket (kuisioner) untuk menilai kualitas produk e-learning pada komponen media ditujukkan kepada ahli media. Aspekaspek yang dinilai meliputi: informasi pendukung, pertimbangan sikap pengguna, kualitas tampilan, navigasi, pedagogik, fitur tak tampak, kehandalan e-learning, dan materi tambahan. Adapun angket (kuisioner) untuk menilai terhadap kualitas materi pembelajaran yang ditujukan kepada ahli materi yang meliputi aspek-aspek: lingkup pembelajaran, informasi pendukung, pertimbangan sikap pengguna, pedagogik, dan materi tambahan. Kemudian aspek yang akan dinilai oleh siswa yang mewakili kemampuan tinggi, sedang, dan rendah, yakni meliputi lingkup pembelajaran, informasi pendukung, pertimbangan sikap, hubungan pengguna dengan e-learning, navigasi, fitur tak tampak, kehandalan $e$ learning, dan materi tambahan.

Kemudian untuk soal pretest dan posttest yang berkaitan dengan indikator, yaitu (1) siswa dapat memahami struktur isi teks anekdot, (2) siswa dapat memahami kaidah teks anekdot, dan (3) siswa dapat memahami makna kata, istilah, dan ungkapan teks anekdot yang berjumlah 25 butir soal. Bentuk tes yang digunakan adalah bentuk tes objektif dengan menggunakan tes pilihan ganda jenis destracters dengan lima arternatif jawaban.

Teknik analisis data menggunakan statistik deskriptif kuantitatif. Data yang diperoleh pada penelitian dan pengembangan ini adalah data kualitatif dan kuantitatif. Data kualitatif berupa saran dan masukan dari dua orang ahli materi dan dua orang ahli media. Data ini kemudian dihimpun dan disarikan untuk memperbaiki kualitas produk yang dikembangkan. Sedangkan data kuantitatif berupa: (1) data penilaian dua orang ahli media, dua orang ahli materi dan tiga orang siswa yang mewakili kemampuan tinggi, sedang, dan rendah. Data yang diperoleh kemudian dikonversikan menjadi data kualitatif skala likert. Skala yang digunakan adalah skala lima dengan mengacu pada rumus konversi yang dikemukakan oleh Sukarjo (2006, p.53). Agar lebih jelas dapat melihat pada Tabel 1 .

Tabel 1. Konversi Data Kuantitatif ke Data Kualitatif Skala 5

\begin{tabular}{|c|c|c|}
\hline \multicolumn{2}{|l|}{ Interval Skor } & \multirow[t]{2}{*}{ Kriteria } \\
\hline Rumus & Rentang & \\
\hline $\mathrm{X}>{\overline{x_{i}}}_{\bar{i}}+1,80 S B_{\mathrm{i}}$ & $X>4,2$ & $\begin{array}{c}\text { Sangat } \\
\text { Baik }\end{array}$ \\
\hline $\bar{x}_{\mathrm{i}}+0,60 S B_{\mathrm{i}}<\mathrm{X} \leq_{\bar{x}_{\mathrm{i}}}^{-}+1,80 S B_{\mathrm{i}}$ & $3,4<X \leq 4,2$ & Baik \\
\hline $\bar{x}_{i_{i}}-0,60 S B_{i}<\mathrm{X} \leq_{\bar{x}_{i}}^{-}+0,60 S B_{i}$ & $2,6<X \leq 3,4$ & Cukup \\
\hline $\bar{x}_{i_{i}^{-}}^{-} 1,80 S B_{i}<\mathrm{X} \leq_{\bar{x}_{i^{-}}}^{-}-0,60 S B_{i}$ & $1,8<X \leq 2,6$ & Tidak Baik \\
\hline $\mathrm{X} \leq_{\bar{x}_{i}}^{-}-1,80 S B_{i}$ & $\mathrm{X} \leq 1,8$ & $\begin{array}{c}\text { Sangat } \\
\text { Tidak Baik }\end{array}$ \\
\hline
\end{tabular}


Keterangan:

$\bar{X}_{i}=$ Rerata skor ideal= $1 / 2$ (skor maksimal ideal + skor minimal ideal)

$S B_{i}=$ simpangan baku ideal=1/6 (skor maksimal ideal-skor minimal ideal)

$X=$ skor aktual

Konversi data kuantitatif ke kualitatif skala 5 tersebut digunakan untuk menentukan produk yang dikembangkan termasuk kriteria layak atau tidak. Produk yang dikembangkan dapat dikatakan layak apabila hasil penilaian uji coba lapangan minimal termasuk dalam kriteria "Cukup" dengan skor 2,6 $<\mathrm{X} \leq 3,4$ sebagai hasil penilaian dari ahli media, ahli materi, dan siswa. Apabila hasil akhir dari semua aspek mencapai setidaknya skor minimal yang telah ditetapkan, maka produk yang dikembangkan layak digunakan sebagai media pembelajaran bahasa Indonesia di SMA Negeri 1 Godean; (2) data hasil uji pre-test dan post-test. Data ini untuk menilai keefektifan produk e-learning yang yang dikembangkan dalam meningkatkan pemahaman isi teks anekdot siswa dengan membandingkan nilai pre-test, dan post-test siswa. Peneliti juga melihat porsentase ketuntasan belajar siswa berdasarkan kriteria ketuntasan minimal di SMA Negeri 1 Godean untuk membatasi KKM "75". Pada penelitian ini peneliti hanya menggunakan satu kelas tanpa menggunakan kelas kontrol, sehingga untuk menghitung besarnya effect size pada penelitian hanya melihat gain.

\section{HASIL DAN PEMBAHASAN}

Hasil penelitian dan pengembangan ini adalah e-learning berbasis Moodle untuk meningkatkan pemahaman isi teks anekdot pada siswa SMA kelas X.

Setelah e-learning dikembangkan menjadi produk awal, kemudian dilanjutkan dengan tahap uji coba alfa dan uji coba beta bertujuan untuk mengetahui kelayakan $e$ learning dari aspek materi dan media sebelum dilanjutkan uji keefektifan e-learning. Uji coba alfa dan beta dengan menggunakan angket yang dikembangkan dari evaluation form (Alessi \& Trollip, 2001, pp.415-417) kemudian divalidasi oleh ahli instrumen. Sedangkan uji efektifan dengan menggunakan soal pretest dan posttest yang dikembangkan dari kompetensi dasar 3.1 memahami struktur dan kaidah teks anekdot baik melalui lisan maupun tulisan; dan 4.1 menginterpretasi makna teks anekdot melalui lisan maupun tulisan yang telah dikonsultasikan pada ahli materi dan guru mata pelajaran bahasa Indonesia.

Adapun hasil uji coba alfa dari ahli materi 1 dan 2 seperti pada Tabel 2 .

Tabel 2. Hasil Uji Coba Alfa Oleh Ahli Materi

\begin{tabular}{clcc}
\hline No & \multicolumn{1}{c}{ Komponen } & Rerata & Kriteria \\
\hline 1. & $\begin{array}{l}\text { Lingkup } \\
\text { pembelajaran }\end{array}$ & 3,8 & Baik \\
\hline 2. & $\begin{array}{l}\text { Informasi } \\
\text { pendukung }\end{array}$ & 3,83 & Baik \\
\hline 3. & $\begin{array}{l}\text { Pertimbangan } \\
\text { sikap pengguna }\end{array}$ & 4,5 & Sangat baik \\
\hline 4. & Pedagogik & 4 & Baik \\
\hline 5. & Materi tambahan & 4 & Baik \\
\hline & Rerata & 3,92 & Baik \\
\hline
\end{tabular}

Berdasarkan Tabel 2 tersebut hasil validasi dua ahli materi pada uji coba alfa secara keseluruhan aspek materi dinyatakan layak berdasarkan rerata skor sebesar 3,92 dengan kategori baik. Skor tersebut berdasarkan hasil rata-rata skor validasi dari masing-masing aspek materi, yakni (1) aspek lingkup pembelajaran dengan rerata skor 3,8 dengan kategori baik; (2) aspek informasi pendukung dengan rerata skor 3,83 dengan kategori baik; (3) aspek pertimbangan sikap pengguna dengan rerata skor 4,5 dengan kategori sangat baik; (4) aspek pedagogik dengan rerata skor 4 dengan kategori baik; dan (5) aspek materi tambahan dengan rerata skor 4 dengan kategori baik. Dari semua aspek tersebut dapat dinyatakan layak untuk dilakukan uji coba selanjutnya karena telah memenuhi standar kelayakan yang telah ditetapkan.

Selanjutnya hasil uji coba alfa dari ahli media 1 dan 2 seperti pada Tabel 3.

Tabel 3. Hasil Uji Coba Alfa Oleh Ahli Media

\begin{tabular}{llcc}
\hline No & Komponen & Rerata & Kriteria \\
\hline 1. & Informasi pendukung & 4,17 & Baik \\
\hline 2. & $\begin{array}{l}\text { Pertimbangan sikap } \\
\text { pengguna }\end{array}$ & 4,5 & Sangat Baik \\
\hline 3. & Kualitas tampilan & 4,25 & Sangat baik \\
\hline 4. & Navigasi & 4,17 & Baik \\
\hline 5. & Pedagogik & 4 & Baik \\
\hline 6. & Fitur tak tampak & 4 & Baik \\
\hline 7. & $\begin{array}{l}\text { Kehandalan } \\
\text { learning }\end{array}$ & 4,25 & Sangat baik \\
\hline 8. & Materi tambahan & 4 & Baik \\
\hline \multicolumn{2}{c}{ Rerata } & 4,17 & Baik \\
\hline
\end{tabular}

Berdasarkan Tabel 3 tersebut hasil validasi dua ahli media pada uji coba alfa secara keseluruhan aspek media dinyatakan layak untuk uji coba selanjutnya berdasarkan rerata skor sebesar 4,17 dengan kategori baik. Skor tersebut berdasarkan hasil rata-rata skor validasi dari masing-masing aspek media, yakni (1) aspek informasi tambahan dengan rerata skor 4,17 dengan kategori baik; (2) aspek 
pertimbangan sikap pengguna dengan rerata skor 4,5 dengan kategori sangat baik; (3) aspek kualitas tampilan dengan rerata skor 4,25 dengan kategori sangat baik; (4) aspek navigasi dengan rerata skor 4,17 dengan kategori baik; (5) aspek pedagogik dengan rerata skor 4 dengan kategori baik; (6) aspek fitur tak tampak dengan rerata skor 4 dengan kategori baik; (7) aspek kehandalan e-learning dengan rerata skor 4,25 dengan kategori sangat baik; (8) aspek materi tambahan dengan rerata skor 4,17 dengan kategori baik. Dari semua aspek tersebut dapat dinyatakan layak untuk dilakukan uji coba selanjutnya karena telah memenuhi standar kelayakan yang telah ditetapkan.

Selanjutnya hasil uji coba beta dari siswa yang mewakili kemampuan tinggi, sedang, dan rendah seperti pada Tabel 4.

Tabel 4. Hasil Uji Coba Beta Oleh 3 Orang Siswa Yang Mewakili Kemampuan Tinggi, Sedang, dan Rendah

\begin{tabular}{llcl}
\hline No & Komponen & Rerata & Kriteria \\
\hline 1. & $\begin{array}{l}\text { Lingkup } \\
\text { Pembelajaran } \\
\text { (subjeck matter) }\end{array}$ & 4,22 & $\begin{array}{l}\text { Sangat } \\
\text { baik }\end{array}$ \\
\hline 2. & $\begin{array}{l}\text { Informasi Pendukung } \\
\text { (Auxiliary informasi) }\end{array}$ & 4,22 & $\begin{array}{l}\text { Sangat } \\
\text { baik }\end{array}$ \\
\hline 3. & $\begin{array}{l}\text { Pertimbangan sikap } \\
\text { (Affective } \\
\text { consideration) }\end{array}$ & 4,67 & $\begin{array}{l}\text { Sangat } \\
\text { baik }\end{array}$ \\
\hline 4. & $\begin{array}{l}\text { Hubungan pengguna } \\
\text { dengan } \text {-learning } \\
\text { (Interface) }\end{array}$ & 4,5 & $\begin{array}{l}\text { Sangat } \\
\text { baik }\end{array}$ \\
\hline 5. & $\begin{array}{l}\text { Navigasi } \\
\text { (Navigation) }\end{array}$ & 5,00 & $\begin{array}{l}\text { Sangat } \\
\text { baik }\end{array}$ \\
\hline 6. & $\begin{array}{l}\text { Fitur Tak Tampak } \\
\text { (Invisible Feature) }\end{array}$ & 3,89 & Baik \\
\hline 7. & $\begin{array}{l}\text { Kehandalan } \\
\text { (Robustness) }\end{array}$ & 4,5 & $\begin{array}{l}\text { Sangat } \\
\text { baik }\end{array}$ \\
\hline 8. & $\begin{array}{l}\text { Materi Tambahan } \\
\text { (Supplementary) }\end{array}$ & Baik \\
\hline Rerata & $\mathbf{4 , 3 9}$ & $\begin{array}{l}\text { Sangat } \\
\text { baik }\end{array}$ \\
\hline & Berrasarkan Tabel & 4 rebut
\end{tabular}

Berdasarkan Tabel 4 tersebut hasil penilaian dari siswa yang mewakili kamampuan tinggi, sedang, dan rendah pada uji coba beta secara keseluruhan dinyatakan layak untuk uji coba selanjutnya berdasarkan rerata skor sebesar 4,39 dengan kategori sangat baik. Skor tersebut berdasarkan hasil rata-rata skor penilaian yakni (1) aspek lingkup pembelajaran dengan rerata skor 4,25 dengan kategori sangat baik; (2) aspek informasi pendukung dengan rerata skor 4,22 dengan kategori sangat baik; (3) aspek pertimbangan sikap pengguna dengan rerata skor 4,67 dengan kategori sangat baik; (4) aspek hubungan pengguna dengan $e$ learning dengan rerata skor 4,5 dengan kategori sangat baik; dan (5) aspek navigasi dengan rerata skor 5 dengan kategori sangat baik; (6) aspek fitur tak tampak dengan rerata skor 3,89 dengan kategori baik; (7) aspek kehandalan dengan rerata skor 4,5 dengan kategori sangat baik; (8) aspek materi tambahan dengan rerata skor 4,17 dengan kategori baik. Dari semua aspek tersebut dapat dinyatakan layak untuk dilakukan uji coba selanjutnya karena telah memenuhi standar kelayakan yang telah ditetapkan.

Kemudian hasil uji efektivitas dari penggunaan sebelum (pre-test) dan sesudah $e$ learning (posttest) oleh siswa SMA Negeri 1 Godean kelas X MIPA yang berjumlah 32 orang siswa. Data pretest, dan posttest dikumpulkan untuk mengentahui efektivitas pembelajaran dengan menggunakan media pembelajaran online (e-learning). Pretest dilakukan sebelum menggunakan e-learning dalam proses pembelajaran. Sedangkan posttest dilakukan setelah proses pembelajaran dengan menggunakan media pembelajaran online $(e$ learning). Media pembelajaran online atau $e$ learning digunakan sebagai media pendukung dalam proses pembelajaran bahasa Indonesia khususnya pada materi teks anekdot pada kompetensi dasar 3.1 memahami struktur dan kaidah teks anekdot baik melalui lisan maupun tulisan; dan 4.1 menginterpretasi makna teks anekdot melalui lisan maupun tulisan.

Proses pembelajaran dengan menggunakan e-learning pada proses pembelajaran dengan menggunakan model $e$ learning Web centric course. Proses pembelajaran dengan menggunakan model tersebut, yakni suatu proses pembelajaran yang dimana memadukan antara pembelajaran jarak jauh, dan tatap muka (konvensional). Ketika proses pembelajaran tatap muka, guru dan peserta bisa mengakses materi pada e-learning, bisa memanfaatkan forum diskusi, kerjakan tugas, dan kuis dll. Ketika proses pembelajaran online penuh atau PJJ, guru dan siswa bisa tetap melaksanakan proses pembelajaran layaknya pada proses pembelajaran dalam kelas konvensional, karena dalam e-learning tersedia fitur-fitur yang menunjang semua kegiatan proses pembelajaran. Misalnya telah tersedia video converence, forum diskusi, kuis, dan tugas dll. 
Kemudian untuk hasil yang diperoleh sebelum dan sesudah menggunakan $e$-learning dapat dilihat pada Tabel 5.

Tabel 5. Hasil Uji Pretest, dan Posttest

\begin{tabular}{lcc}
\hline \multicolumn{1}{c}{ Data } & \multicolumn{2}{c}{ Nilai } \\
\cline { 2 - 3 } & Pretest & Posttest \\
\hline Nilai Tertinggi & 76 & 100 \\
\hline Nilai Terendah & 54 & 76 \\
\hline Jumlah & 2140 & 2996 \\
\hline Rata-rata & 66,88 & 93,63 \\
\hline Gain & \multicolumn{2}{c}{$\mathbf{7 5}$} \\
\hline
\end{tabular}

Berdasarkan dari Tabel 5 tersebut hasil

belajar siswa sebelum menggunakan e-learning (pretest) diperoleh rata-rata 66,88, dan sesudah menggunakan e-learning (posttest) diperoleh rata-rata 93,63 dan kemudian selisih antara pretest, dan posttest rata-rata sebesar 26,75. Kemudian ditinjau dari KKM (75) dengan skor disetiap siswa (terendah 76, dan tertinngi 100) maka hasil yang dicapai siswa dari proses pembelajaran dengan menggunakan media pembelajaran online dinyatakan bahwa $100 \%$ siswa telah mencapai KKM. Dengan hasil tersebut dapat disimpulkan bahwa pembelajaran menggunakan e-learning berbasis Moodle dianggap efektif dalam meningkatkan pemahaman isi teks anekdot pada siswa SMA kelas X.

\section{PENUTUP}

Berdasarkan hasil penelitian dan pengembangan, dapat disimpulkan bahwa (1) E-learning berbasis Moodle untuk meningkatkan pemahaman isi teks anekdot anekdot pada siswa SMA Kelas X dihasilkan sesuai dengan model pengembangan Alessi dan Trollip (2001) melalui tiga tahap, yakni (a) perencanaan meliputi: menetapkan bidang atau ruang lingkup kajian, mengidentifikasi karakteristik peserta didik, menentukan dan mengumpulkan sumber-sumber, dan melakukan brainstorming; (b) perancangan meliputi: melakukan analisis konsep, membuat flowchart, dan membuat layout; (c) pengembangan meliputi: membangun e-learning dengan domain dan hosting, mengembangkan konten, menggabungkan bagian-bagian, menyiapkan materi-materi tambahan, tes alfa, revisi, tes beta, revisi, dan uji efektivitas. Setelah melakukan tiga tahap pengembangan tersebut kemudian menghasilkan produk e-learning berbasis Moodle untuk meningkatkan pemahaman isi teks anekdot pada siswa SMA kelas $\mathrm{X}$ yang layak dari aspek materi, dan media; (2) E-learning berbasis Moodle untuk meningkatkan pemahaman isi teks anekdot anekdot pada siswa SMA Kelas X dinilai layak dari aspek materi dan media. Kelayakan tersebut dapat dilihat dari hasil uji alfa dari ahli materi 1 dengan rerata sebesar 3,60 dengan kategori "Baik", ahli materi 2 dengan rerata skor sebesar 4,24 dengan kategori "Sangat Baik"; kemudian oleh ahli media 1 dengan rerata skor sebesar 4,26 dengan kategori "Sangat Baik", ahli media 2 dengan rerata skor sebesar 4,48 dengan kategori "Sangat Baik"; selanjutnya juga di dari hasil uji beta dari penilaian oleh siswa dengan rerata skor sebesar 4,23 dengan kategori "Sangat Baik"; dan (3) efektivitas pembelajaran Bahasa Indonesia khususnya untuk meningkatkan pemahaman isi teks anekdot pada siswa SMA kelas X dengan menggunakan e-learning berbasis Moodle dinyatakan efektif dilihat dari peningkatan pencapaian hasil belajar siswa sebesar $26,75 \%$. Nilai rata-rata pretest 66,88 meningkat pada posttest menjadi 93,63. dengan persentase ketuntasan pencapaian KKM sebesar $100 \%$.

Adapun saran dalam penelitian ini adalah sebagai berikut, (1) E-learning berbasis Moodle ini perlu diimplementasikan lebih lanjut agar diketahui kelemahan dan kekurangannya dalam proses pembelajaran; (2) Materi pelajaran bahasa Indonedia yang ada pada $e$ learning perlu ditambahkan agar pembelajaran dalam satu semester bisa dibantu secara menyeluruh melalui e-learning; (3) Materi yang disajikan di e-learning tidak hanya mata pelajaran bahasa Indonesia tetapi juga mata pelajaran lainnya; (4) Pendidik/guru diharapkan mampu memanfaatkan e-learning ini untuk meningkatkan hasil belajar siswa.

\section{DAFTAR PUSTAKA}

Alessi, S.M. \& Trollip, S.R. (2001). Multimedia for learning: methods and development. Massachusetts: Pearson Education Company.

Amiruddin, Y.A. (2013). Kedudukan materi pelajaran bahasa Indonesia di kurikulum 2013. Diambil pada tanggal 1 Januari 2016 , dari https://campuscemara.wordpress.com/20 13/04/15/kedudukan-materipelaj aranbahasa-di-kurikulum-2013/.

Arkorful, V., \& Abaidoo, N. (2014). The role of e-learning, the advantages and disadvantages of its adoption in. International Journal of Education and Research, 2, 397-410. 
Arsyad, A. (2014). Media pembelajaran. Jakarta: Rajawali Pers

Baskoro, D.G. (2014). Menggunakan moodle: pengantar. Diambil pada tanggal 30 Oktober 2015, dari http://122.200.2.50/Portals/0/MENGGU NAKAN\%20MOODLE.pdf.

Chaer, A. (2007). Linguistik umum. Jakarta: Rineka Cipta.

Clark, R.C., \& Mayer, R.E. (2008). E-learning and the science of instruction: proven guildelines for consumers and designers of multimedia learning second edition. San Francisco: Pfeiffer.

Conrad, K., \& TrainingLinks. (2000). Instructional design for web-based training. Amherst: HRD Press.

Depdiknas. (2007). Himpunan PerundangUndangan Republik Indonesia, Humas Depdiknas, Jakarta.

Hartawan, I.K.A, Tastra, D.K, \& Pudjawan, K. (2014). Pengembangan portal e-learning berbasis moodle pada mata pelajaran fisika kelas x di sma dwijendra denpasar. E-jurnal edutech Universitas Pendidikan Ganesha Jurusan Teknologi Pendidikan, Vol: 2 No: 1 Tahun 2014.

Helianak, A.S., \& Surjono, D.S. (2014). Pengembangan e-learning mata pelajaran teknologi informasi dan komunikasi (tik) di sma negeri 3 kupang. Jurnal Inovasi Teknologi Pendidikan, 1 (1), 1-14. Retrieved from http://journal.uny.ac.id/index.php/jitp/arti cle/view/2455/2041

Horton, W. (2006). E-learning by design. San Fransisco: Pheiffer.

Horton, W. \& Horton, K. (2003). E-learning tools and technologies: a consumer's guide for trainers, teachers, educators and instructional designers. New York: Wiley Publishing, Inc.

Isaías, P., Ifenthaler, D., Spector, J.M., \& Sampson, D.G. (2015). E-Learning systems, environments and approaches: theory and implementation. New York: Springer.

Keraf, G. (2004). Komposisi. Semarang: Nusa Indah.

Munandar. (2015). Analisis kebutuhan laboran SMA Negeri 1 Godean. Sleman: tidak diterbitkan

Nurhadi. (2010). Pengembangan e-learning pembelajaran pendidikan kewarganegaraan untuk sekolah lanjutan tingkat atas. Tesis magister, tidak diterbitkan, Universitas Negeri Yogyakarta, Yogyakarta.

Prawiradilaga, D.S., Ariani, D., \& Handoko, H. (2013). Mozaik teknologi pendidikan elearning. Jakarta: Kencana Prenada Media Group.

Rahmayanti, D., Martha, I.N., \& Wisudariani, N.M. (2015). Pembelajaran menulis teks anekdot pada mata pelajaran bahasa Indonesia dalam kurikulum 2013 di kelas x.a akuntansi smk negeri 1 singaraja. $e$ Journal JPBSI Universitas Pendidikan Ganesha Jurusan Pendidikan Bahasa dan Sastra Indonesia, Volume 3 No 1 Tahun 2015

Rusman, Kurniawan, D., \& Riyana, C. (2012). Pembelajaran berbasis teknologi informasi dan komunikasi. Depok: Rajawali Pers.

Sadiman, A.S., Rahardjo, R., Haryono, A., \& Rahardjito. (2012). Media pendidikan. Jakarta: Rajawali Pers.

Srivastava, E., \& Agarwal. (2013). E-learning: new trend in educational and training. International Journal of Advanced Research, 1,(8), 797-810.

Sufanti, M. (2010). Strategi pengajaran bahasa dan sastra indonesia. Surakarta: Yuma Pustaka.

Sukarjo. (2006). Kumpulan materi evaluasi pembelajaran. Yogyakarta: Universitas Negeri Yogyakarta.

Surjono, H.D. (2013). Membangun course elearning berbasis moodle. Yogyakarta: UNY Pres.

\section{PROFIL SINGKAT}

Abdul Haris Munandar, lahir di Bima Nusa Tenggara Barat pada tanggal 15 September 1988. Menyelesaikan pendidikan S1 pada program studi Pendidikan Bahasa, Sastra Indonesia dan Daerah Fakultas Keguruan, dan Ilmu Pendidikan Universitas Muhammadiyah Mataram pada tahun 2013. Kemudian pada tahun 2014 melanjutkan studi di program studi Teknologi Pembelajaran Pascasarjana Universitas Negeri Yogyakarta.

Herman Dwi Surjono, lahir di Sidoarjo Jawa Timur pada tanggal 5 Februari 1964. Menyelesaikan S-1 pada program studi Pendidikan Teknik Elektronika di IKIP Yogyakarta. Kemudian melanjutkan S-2 pada program studi Industrial Ed. And Technologi di 
Iowa State University USA. Kemudian mengambil S-2 lagi pada program studi Sistem Komputer dan Informatika di Universitas Gajah Mada Yogyakarta. Kemudian melanjutkan S-3 pada program studi Information Technology di Southern Cross University Australia. Kemudian pada tahun 2015 di kukuhkan sebagai Guru Besar dalam Ilmu Pembelajaran Teknologi Informasi pada Fakultas Teknik Universitas Negeri Yogyakarta. Saat ini menjabat sebagai Ketua Program Studi Teknologi Pembelajaran Pascasarjana Universitas Negeri Yogyakarta. 